\title{
Analysis of Sustainable Tourism Performances of Eastern Black Sea Region Provinces* $^{*}$
}

\section{Doğu Karadeniz Bölgesi İllerinin Sürdürülebilir Turizm Performanslarının Analizi}

\author{
Dr. Öğr. Üyesi İsmail ÇALIK \\ Gümüşhane Üniversitesi \\ Turizm Fakültesi \\ E-posta:ismailcalik29@gmail.com
}

\author{
Prof.Dr. Orhan BATMAN \\ Sakarya Uygulamalı Bilimler Üniversitesi \\ Turizm Fakültesi \\ E-posta:obatman@subu.edu.tr
}

\begin{abstract}
The research aims to determine the sustainable tourism indicators specific to the Eastern Black Sea Region of Turkey and to make inferences about the tourism performance of the region under the light of pre-determined indicators. To fulfill this purpose, qualitative and quantitative methods were employed together in the research. The secondary data used in the research were obtained from the time series published by the relevant public institutions between 2008/2012. As for the qualitative research, the data were collected by using a semi-structured interview technique. As a result of the research, it may be commented that the sustainable tourism performances of the provinces in the region remained at low levels according to the total values of the sustainable performance index and alleged that meaningful problem fields that may constrain sustainable tourism development in the region exist.
\end{abstract}

Key Words: Sustainable Tourism Indicators, Eastern Black Sea Region, Turkey.

\section{Öz}

Bu araştırmada, Doğu Karadeniz Bölgesi'ne özgü sürdürülebilir turizm göstergelerinin belirlenmesi ve belirlenen göstergeler ışığında bölgenin turizm performansı hakkında çıkarımlar yapılması amaçlanmaktadır. Araştırmada nitel ve nicel yöntemler bir arada kullanılmıştır. Araştırmada kullanılan ikincil veriler, 2008/2012 yılları arasında ilgili kamu kurumları tarafından yayınlanan zaman serilerinden elde edilmiştir. Nitel araştırmada kullanılan veriler ise yarı yapılandırılmış görüşme tekniği kullanılarak toplanmıştır. Araştırma sonucunda, bölge illerinin sürdürülebilir turizm performanslarının, sürdürülebilir performans endeksi toplam değerleri sonuçlarına gore düşük seviyelerde kaldığı ve bölgede sürdürülebilir turizm gelişimini engelleyecek ciddi sorun alanlarının bulunduğu söylenebilir.

Anahtar Kelimeler: Sürdürülebilir Turizm Göstergeleri, Doğu Karadeniz Bölgesi, Türkiye.

Bu çalışma 30.04.2014 tarihinde, "Sürdürülebilir Turizm Göstergeleri Bağlamında Doğu Karadeniz Bölgesi'nin Analizi” adlı doktora tezinden türetilmiştir. 


\section{Introduction}

Tourism sector has been among the most important development options, especially for the developing and underdeveloped countries since the second half of the 20th century. It is estimated that international tourism arrivals, which were 674 million people in 2000 , reached 949 million in 2010 , will reach 1.56 billion 2020 (UNWTO, 2020) and 1.8 billion in 2030 (United Nations World Tourism Organizations, 2015: 4). In parallel with this development, it may be uttered that tourism has unique characteristics and can constitute opportunities for the achievement of sustainable development. Actually tourism sector provides relatively environmental and renewable options as against sectors such as textile, mining, and forestry shows the role of tourism in achieving sustainable development goals. In addition, the natural (sea, sand, sun, natural life), historical and socio-cultural resources, which are found free of charge in the nature, are more available in less developed countries, reinforcing the stated role of tourism (Speier, 2005: 2).

Tourism serves for multiple benefits to developing and underdeveloped countries in terms of contributing to the regional economy, such as increasing employment, maximizing foreign exchange revenues, reducing poverty, increasing tax revenues, positive impacts on balance of payments, activating other sectors and raising per capita income. It is also argued that the tourism contributes to strengthening the economy of the region, increasing recreation areas open to the use of local people, confidence of the local people as well as kindness and mutual trust, and contributing to the general quality of life (Aspinall, 2006:1; Bahar and Kozak, 2010: 155-170; Goodwin, 1998: 2; Tosun, 2002: 245).

Despite the given positive effects, some economic, socio-cultural and environmental damages originating from tourism arise. Activities damaging the natural environments as traffic, crowd, architectural pollution, exceeding the limits of physical carrying capacity, solid wastes, construction in sensitive areas, erosion, emission and greenhouse gas formation, overfishing, and so on are increasing the environmental damage in tourism destinations. The increase of common crimes such as snobbism, prostitution, language disputes, murder and theft, the commodification of cultural values, negatively affect intra-family relations and identity conflicts caused by cultural interaction can be considered among the socio-cultural negativities caused by tourism. The increase in prices, inflation, leaks, the inability of the local people to play an active role in the economic management and planning processes namely the inability to resort to the opinions of local people in the decision-making process and the opportunity costs can be considered among the economical negativities caused by tourism (Bal, 1995; Liu, 2003; Reilly, 2008; Sharpley, 2006: 103-132; Choi and Sirakaya, 2006: 1274; Tanquay, Therrinen and Rajaonsen, 2011).

In line with sustainable development, there are some factors that enable the development of sustainable tourism options. For example, minimizing the economic, socio-cultural and environmental obstacles stemming from tourism, observing the extent of the destruction and determining which strategies should be implemented to eliminate this destruction. Sustainable tourism development requires that social, economic and environmental objectives be determined by long-term planning and by consulting the opinions of all stakeholders (Murphy and Price, 2005: 175). Sustainable tourism, defined as the satisfaction of the needs of tourists and local people without disregarding the needs of future generations (Kahraman and Türkay, 2014: 112), is a combination of nature-friendly tourism activities, protection of local heritage, active participation of local people in tourism planning and implementation processes, the calculation of carrying 
capacity, the guiding of sustainable tourism indicators, and the carrying out the planning process. One of the methods used to measure the sustainability aspects of tourism activities is the usage of sustainable tourism indicators (Farsari and Practacos, 2001:1). Pre-determination of the problems that will emerge from sustainable tourism indicators is a frequently used method for measuring and identifying the results of activities to solve the problem and to observe the risks and potential risk elements, which seem to be the main source of problems (UNWTO, 2004: 8).

Nowadays using indicators in the context of sustainable tourism has become one of the prominent subjects. International organizations such as the United Nations World Tourism Organization, statistical organizations, World Tourism and Travel Council, national and local governments are carrying out significant studies for establishing appropriate indicators to measure sustainability in tourism (Ceron and Dubais, 2003: 5456). The most comprehensive study in the literature on sustainable tourism indicators is the work of the United Nations World Tourism Organization, "Guide for Sustainable Development Indicators for Tourism Destinations". Besides, numerous studies including ecological coverage, carrying capacity, sustainable social tourism indicators, etc. have been performed in different times (Choi and Sirakaya, 2006: 1275; Hunter and Shaw, 2007: 46; Miller, 2001: 351; Tokmak, 2008; UNWTO, 2004).

In this study, the Eastern Black Sea Region was tackled under the light of sustainable tourism indicators. Firstly, the indicators were picked up in order to make evaluations from the sustainable tourism indicator list formulated by the UNWTO. Gained from the time series studies of the related public institutions, the data related to the selected indicators were then analyzed and were examined through the sustainable performance index method in order to carry out comparisons between the regions. On the other hand, the main motivation for the preparation of this work is that the sustainable tourism approach is based on cultures, investors, businesses, people, decision-makers, tourists, academicians, developing holistic suggestions for distinct interest groups, and that planning activities that may be determined and realized by the guided indicators will reduce the extent of the destruction that will create tourism in the region. Furthermore, in order to protect environmental and cultural values with the contribution of tourism and to maintain the balance of protection / use in the Eastern Black Sea Region where the tourism arrivals are relatively less intensive, determining the principles of sustainable tourism indicators at the beginning stage and measuring the extent of destruction in destinations through indicators will contribute to all stakeholders in the region in the medium and long term.

\section{Research Method}

\subsection{Quantitative survey}

In the study, indicator data sets obtained by compiling time series studies announced by related institutions were used. Indicators are frequently used method of predicting the problems that will arise, measuring and identifying the results of activities to eliminate the problem and to observe the risks and potential risks that are the main source of problems, (UNWTO, 2004: 8). Sustainable tourism indicators bolster practitioners not only to measure sustainable elements but also to identify environmental and social issues, defining social capacity limits, detailing sustainable development goals and optimal management strategies (Schianetz and Kavanagh, 2008: 604).

Prior to the selection of sustainable tourism indicators, it has been deemed appropriate to choose and measure the indicators from the perspective of the Eastern 
Black Sea Region among the 140 indicators determined by the UNWTO, where meaningful data may be made use of (UNWTO, 2004). While determining the indicators, it needs to be noted that there are some specific limitations. For instance, certain indicator datasets do not allow to execute comparisons over the years and a few public institutions are not willing to share their indicator data. In this study, indicator themes were specified under four headings as economic, socio-cultural, environmental and planning and control. Then 16 indicator themes and 37 indicators were determined related to the Eastern Black Sea Region. Having elected the indicators, sustainable performance index method was used to make comparisons between provinces. Sustainable tourism indicator datasets for the years between 2008 and 2012 were used for Artvin, Giresun, Gümüşhane, Ordu, Rize and Trabzon, which are the provinces located in the Eastern Black Sea Region of Turkey (TR90). These indicators are in shown Table 1.

Table 1: Sustainable tourism indicators of Eastern Black Sea Region

\begin{tabular}{|c|c|}
\hline $\begin{array}{l}\text { Indicator } \\
\text { Type }\end{array}$ & Indicator Theme and Indicators \\
\hline & Development of Touristic Overnight Stay (6 indicators) \\
\hline \multirow{17}{*}{ 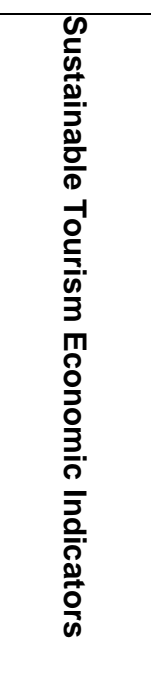 } & 1)Number of Guests in Accommodation Facilities certified by Ministry of Culture and Tourism \\
\hline & 2)Number of Guests in Accommodation Facilities certified by Municipality \\
\hline & 3)Number of Nights in Accommodation Facilities certified by Ministry of Culture and Tourism \\
\hline & 4)Number of Nights in Accommodation Facilities certified by Municipality \\
\hline & 5)Occupancy Rates in Accommodation Facilities certified by Ministry of Culture and Tourism \\
\hline & 6)Occupancy Rates in Accommodation Facilities certified by Municipality \\
\hline & Development of Railway and Airline Arrivals (4 indicators) \\
\hline & 1)Number of Aircraft Landing / Departing \\
\hline & 2) Number of Passengers in Aircrafts \\
\hline & 3)Number of Passengers Traveling by Cruise Ship \\
\hline & 4)Number of Vehicles Carried with Ro-Ro Vessels \\
\hline & $\begin{array}{l}\text { Variety of Accommodation Types and the Priority of the Services of the Region ( } 3 \\
\text { indicators) }\end{array}$ \\
\hline & 1)Bed Capacity in Accommodation Facilities certified by Ministry of Culture and Tourism \\
\hline & 2)Bed Capacity in Accommodation Facilities that has Tourism Investment Certification \\
\hline & 3)Bed Capacity in Accommodation Facilities certified by Municipality \\
\hline & Development of Touristic Investments ( 1 indicator) \\
\hline & 1)Public Tourism Investments \\
\hline \multirow{15}{*}{ 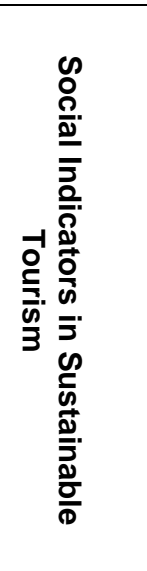 } & Net Migration Rate (1 indicator) \\
\hline & 1)Net Migration Rate \\
\hline & Information on Local Culture, Preservation of Intangible Cultural Heritage (2 indicators) \\
\hline & 1) Folk Culture Field Research by Ministry of Culture and Tourism \\
\hline & 2)Research for the Conservation of Intangible Cultural Heritage \\
\hline & The Quality, Variety and Number of Cultural Environments ( 3 indicators) \\
\hline & 1)Cinema Audience Numbers \\
\hline & 2)Theater Audience Numbers \\
\hline & 3)Number of Public Library Use \\
\hline & General Situation of Contemporary, Traditional, Monumental Heritage (2 indicators) \\
\hline & 1)Restoration Project Numbers \\
\hline & 2)Restoration Project Amounts \\
\hline & General Situation of Health Services (2 indicators) \\
\hline & 1)Number of Hospital Staff \\
\hline & 2) Bed Capacity at Hospitals \\
\hline
\end{tabular}


Continuation of Table 1

\begin{tabular}{|c|c|}
\hline \multirow{15}{*}{ 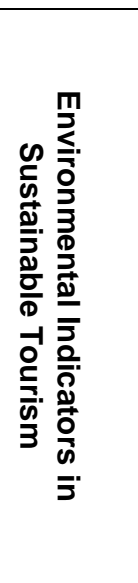 } & Solid Waste Collection, Reuse and Conversion Systems (2 indicators) \\
\hline & 1)Solid Waste Collected by Municipalities \\
\hline & 2Proportion of Waste Service Population to Total Population \\
\hline & Emission Level and Atmospheric Pollution (2 indicators) \\
\hline & 1)Annual Average Sulfur Dioxide (SO2) Values \\
\hline & 2)Annual Average Particulate Matter Values (PM10) \\
\hline & Sustainable Forestation Areas and Erosion Control Studies (2 indicators) \\
\hline & 1)Afforestation Activities \\
\hline & 2)Erosion Control Activities \\
\hline & Capacity and Availability of Renewable Energy Reserves and Network (2 indicators) \\
\hline & 1)Installed Capacity of Hydroelectric Power Plants \\
\hline & 2)Gross Production Amount of Hydroelectric Power Plants \\
\hline & Use of Natural Resources in Places of Tourism (2 indicators) \\
\hline & 1)Organic Farming Production Amount \\
\hline & 2)Organic Farming Fields \\
\hline & Activity of Planning, Control and Management Systems (2 indicators) \\
\hline$\stackrel{0}{\underline{n}}$ & 1) Number of Tourism Projects Supported by Eastern Black Sea Development Agency \\
\hline 亏 & 2) Amount of Tourism Projects Supported by Eastern Black Sea Development Agency \\
\hline$\stackrel{\overline{\overbrace{}}}{\varrho}$ & Corporate Consultation and Communication Efforts (1 indicator) \\
\hline 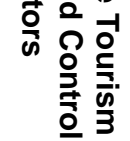 & $\begin{array}{l}\text { 1)Meetings, Trainings and Seminars for Tourism Sector Stakeholders organized by Eastern } \\
\text { Black Sea Development Agency }\end{array}$ \\
\hline
\end{tabular}

Source: Adopted from UNWTO (2004).

\subsubsection{Data analysis method}

\section{Sustainable Performance Index Method}

A sustainable performance index is described as a measurement technique that plays a vital role in measuring indicators and in making decisions based on these measured values. This method is used to assess the sustainable performance of an integrated sustainable development index (Castellani, 2009).

\section{Determination of Sustainable Performance Index Value}

Sustainable performance index value is known as the integrated value of identified indicators;

$$
S P=\quad \sum_{\mathrm{i}=1}^{20} I i \quad[1]
$$

In the sustainable performance index method, each indicator that is initially set takes a value between 0 and 10 . These values represent the level of sustainable development for that indicator. If the relationship between the value of the subject and the value of the indicator gives the correct ratio, the value of this indicator is calculated in the 2nd equation. For example, a direct relationship between education level and sustainable performance may come out. If there is an inversely proportional relationship between the value of the subject and the value of the indicator, that is, if an indicator value increases while the other value decreases, then equation 3 is employed. For instance, as the level of urbanization goes up, sustainable performance decreases.

These equations used in the calculation of the indicator value are listed below: 


$$
\begin{array}{lll}
\mathrm{li}= & (\mathrm{S}-\mathrm{s}) /(\mathrm{Vi}-\mathrm{vi})^{*} \mathrm{xi}+\mathrm{S}-((\mathrm{S}-\mathrm{s}) /(\mathrm{Vi}-\mathrm{vi}))^{*} \mathrm{Vi} \\
\mathrm{li}= & -(\mathrm{S}-\mathrm{s}) /(\mathrm{Vi}-\mathrm{vi})^{*} \mathrm{xi}+\mathrm{S}+((\mathrm{S}-\mathrm{s}) /(\mathrm{Vi}-\mathrm{vi}))^{*} \mathrm{Vi}
\end{array}
$$

In the study, tables of index values for illicit drugs for the years 2008, 2009, 2010, 2011 and 2012 were prepared using the above-mentioned formulas and the index values in the tables were collected and the total values of the sustainable performance indexes in the specified years were calculated for each province.

\subsection{Qualitative Survey}

In the study, 71 tourism stakeholders in the Eastern Black Sea Region were interviewed via a semi-structured survey in order to identify the problem areas and the strengths of sustainable tourism. The results of the interviews have been supplied in the findings chapter. In the analysis of qualitative data, descriptive analysis method was used. The results of the sustainable tourism indicators and semi-structured interviews, which were obtained by analyzing the secondary data in the findings, were presented together. The details about the interviewed stakeholders are shown in Table 2.

\section{Table 2: Sustainable tourism stakeholders interviewed in Provinces of Eastern Black Sea Region}

\begin{tabular}{|l|c|c|c|c|c|c|c|}
\hline $\begin{array}{l}\text { Sustainable } \\
\text { tourism } \\
\text { stakeholders }\end{array}$ & Artvin & Giresun & Gümüşhane & Ordu & Rize & Trabzon & Total \\
\hline $\begin{array}{l}\text { Tourism } \\
\text { academics }\end{array}$ & 4 & 3 & - & 1 & - & 2 & 10 \\
\hline $\begin{array}{l}\text { Hospitality } \\
\text { businesses }\end{array}$ & 2 & 1 & - & 6 & 4 & 12 & 25 \\
\hline Travel agencies & - & 2 & 1 & 1 & 2 & 3 & 9 \\
\hline Tour guides & - & - & - & - & 2 & 3 & 5 \\
\hline Mayors & - & 2 & - & - & 2 & 8 & 12 \\
\hline $\begin{array}{l}\text { Public tourism } \\
\text { managers }\end{array}$ & 1 & 2 & 1 & 1 & - & 1 & 6 \\
\hline $\begin{array}{l}\text { Civil society } \\
\text { organizations }\end{array}$ & - & - & 1 & - & 1 & 2 & 4 \\
\hline Total & 7 & 10 & 3 & 9 & 11 & 31 & 71 \\
\hline
\end{tabular}

\section{Research Findings}

In this part of the study, the findings concerning the sustainable tourism indicator survey of the Eastern Black Sea Region have been pointed out. It is observed that the total number of residents, number of overnight stay and occupancy rates in tourism businesses and accommodation businesses certified by municipality, which are among the economic indicators of sustainable tourism, have risen again since 2010 even though the provinces in all the region have declined in 2009 and 2010. It can be said that the economic crisis experienced in Turkey in 2009 may be the main cause of this situation. Despite the demand increase on the region by locals and foreign tourists, many problems related to tourism businesses in the region have been voiced in interviews with tourism stakeholders. The fact that the tourism movements are affected by several 
factors such as illegal accommodation businesses, travel agencies and tourist guidance activities, the lack of suitable materials for tourism investments, the effects of short term economic interests on investment decisions, architectural pollution caused by investments in non-zoned tourism enterprises in the tablelands, inability to employ qualified personnel in tourism business due to excessive working hours, seasonality, low wages etc., travel agencies' being insufficient to prepare package tours and to attract tourists outside the region are just some of these problems.

One of the economic indicators of sustainable tourism is the development of arrivals of tourists traveling to the region by rail, sea and air. It can be said that the number of airplanes landing in/ departing from Trabzon Airport, which is the only airport in operation between 2008-2012, and the number of passengers increased gradually. Besides, the Ordu-Giresun Airport opened in 2015 may contribute to the rise of tourist arrivals to the region. Since there is no railway transport in the area, there is no data on this indicator. Even though there are ports in Ordu, Giresun, Rize, Trabzon and Artvin in Eastern Black Sea Region, Trabzon port is the only port where cruise ships drop anchor. Tourism statistics including the Trabzon port cruise ships have gone up between 2008 and 2010 but witnessed the lowest number of tourists among the five years in 2011. Yet, the statistics about the tourists that traveled by cruise ships were the highest in five years in 2012. Despite these statistics, it is believed that the demand for cruise tourism to the region is not at the desired level compared to the other regions. For this reason, public institutions and tourism businesses in the region should make use of promotional activities for different tourist groups (family, young people, luxury tourists, conservative tourists).

The variety of accommodation types and the prominent features of the offerings in the region are covered by changes in the bed capacities of tourism businesses, investment certificates by ministry of culture and tourism and accommodation businesses certified by municipality. When the statistics are examined, it may be conceived that bed capacity of the accommodation businesses in the region has increased. However, it should be noticed that related statistics do not include tourism businesses operating in tourism areas such as Uzungöl, Ayder Plateau, where tourism activities in the region are carried out without building and having any operating certification. In the interviews with stakeholders residing in this region, has been observed that the local people tend to operate in tourism management activities that are not in compliance with the law due to the concentration of tourist demand and zoning problems.

On the other hand, it can be said that with the change of land use patterns in tablelands, there are active residentials, recreation facilities and tourism businesses in the region, which would harm the economic, socio-cultural and environmental sustainability elements of tourism. The reasons why this damage takes place are that public institutions failed to prevent illegal construction in the regions for different reasons, the local people lack consciousness about plateau tourism, there are bureaucratic obstacles caused by the legislative special state of the plains and the migrating locals carried their urban habits to the highlands. In the study conducted by Somuncu et al. (2012), it is stated that the most important legal problem in the region is the ownership status of the highlands and the difficulties in the implementation of the Pasture Law No. 4342.

Despite the clear provisions of the pasture law, the way to benefit from tablelands, constructions built for shelter, recreation and tourism facilities and ownership problem of these structures are the main obstacles in tablelands. Likewise, there are other 
dilemmas such as failure in vegetation cover, solid and liquid waste management problems and noise pollution due to the traffic caused by the change depending on the usage of the tablelands (Somuncu et al. 2012: 222 and 223). In order to overcome these issues, it is suggested that a scientific approach should be taken to determine the limits of carrying capacity and change limits of the region, to support the house pension system instead of giving the tourism services to the non-traditional structures, to apply the legal sanctions to reduce environmental degradation, to pass on long-term tourism plans including the topics such as accommodation areas, green areas, recreation areas, etc., and to install the standards for the facilities in these areas under the guidance of the stakeholder opinions.

Tourism is one of the basic indicators of sustainable tourism that may provide the local people with sustainable economic benefits. In this context, it is expected that investments in tourism businesses be realized in the regions where sustainable tourism approach is adopted through smaller-scale investments by which local people play more active roles rather than the investments in hotel chains. In this context, the hometown of accommodation businesses owners and employed personnel in the region are among the basic economic indicators of sustainable tourism. When the region is appraised in terms of this indicator, it can be said that about $90 \%$ of the accommodation businesses were run by local actors, and local employees were recruited in similar proportions. While this may seem to be a key strength of the region, it might be constructive to administer in-service trainings for the employees and owners operating in the region regarding some topics like accommodation, institutionalization, service quality improvement and guest satisfaction.

It is an important requirement in terms of sustainable performance in the monitoring of goods and service processes through certification and the control of the enterprise by professional standardization organizations in tourism enterprises. It can be said that $60 \%$ and more of the accommodation businesses operating in the region do not have any national or international certificates. The "Green Star" certificate issued by the Ministry of Culture and Tourism to hotels that use environmentally sensitive applications in the provision of goods and services is only available in two hotels in the region. It was declared during the interviews by some of sustainable tourism stakeholders that some hotels have been registered to obtain an environmentally friendly hotel certificate.

The net migration rate takes its place among the social indicators of sustainable tourism. The net migration rate is the difference between the migration from a region and the migration it receives. The migration of the young population especially from the region can be regarded as a negative indicator in terms of the tourism sector. It may be asserted that it may be difficult to employ qualified personnel in regions where the rate of net migration is quite high because the average age of employed personnel in tourism enterprises is between the ages of 18-35.

The Eastern Black Sea Region is one of the most intensely immigrating regions of Turkey. It was determined that there are positive and negative changes in the immigration values between 2008 and 2012. Accordingly, the immigration characteristic of the region continues in some of the provinces. For example, the migration receiving amount is more than the migration sending in 2012 in Gümüşhane, Ordu and Giresun, but the net migration rate in Trabzon and Rize provinces is negative. According to these results, while negative rates of migration rates in Trabzon and Rize provinces where tourism is concentrated in the region are a negative factor in terms of sustainable tourism, reverse migration movements towards Ordu, Giresun, Gumushane and Artvin 
provinces may results in positively for the regional tourism. It should be highlighted that the migration structure of the region affects the sustainability of the region negatively in many aspects, especially in the employment of experienced and qualified personnel. On the other hand, it can be said that people who migrate to metropolitan cities and return to the region after a certain time may have negative effects especially in some fields such as reinforced concrete building, transferring urban culture rituals to tablelands, whereas they may have positive impacts in some fields such as the use of the tourism experiences obtained in the cities, and return of the acquired capital as a tourism investment in the region.

Among the social indicators of sustainable tourism, the educational level of the employed personnel in tourism businesses and female employment in tourism enterprises are critical indicators. When the education levels of the personnel employed in the hospitality businesses in the district provinces are evaluated, it was noticed that $70 \%$ of the employees hold primary and secondary education levels. What is more, it was spotted that the proportion of graduates of vocational schools and undergraduate education institutions providing formal tourism education is only $10 \%$. In addition, in interviews with regional tourism stakeholders, it has been emphasized by almost all of the enterprises that qualified and trained personnel cannot be employed in tourism businesses.

The main reasons of trained staff employment problems stated by the sustainable tourism stakeholders are the scarcity of higher education institutions in the region and the lack of qualified foreign language education in higher education institutions where tourism education is provided. Furthermore, waitresses, receptionists, etc. tourism professions are not considered as a permanent job. It was also obtained that young people were not interested in tourism professions due to seasonality, low wages and excessive working hours. However, if the tourism-school graduate consent to work in the sector, they prefer to engage in more developed regions like Antalya and Muğla. In the solution of the qualified personnel problem, it is recommended to ensure that the professional competence rules related to tourism professions are brought into effect by legal regulations, periodically supervised by the relevant public institutions, and that measures are taken to make it easier for young people to prefer tourism professions. In addition, it was identified that the rate of female staff employed in the hospitality enterprises in the region is $25 \%$. Once the international data, indicating that the average rate of female employees working in businesses in the tourism sector is $50 \%$, is taken into account, it can be accentuated that the number of women employed in the hospitality businesses in the region is rather low.

In the region, context of information on local culture and the protection of intangible cultural heritage indicators, folk culture field studies and intangible cultural heritage studies carried out by the Ministry of Culture and Tourism in the provinces of the region were discussed. Besides, projects related to the intangible cultural heritage supported by the Eastern Black Sea Development Agency were evaluated within this scope. It should be noted that within the scope of the subject, although a limited number of projects and field studies were carried out in 2008-2012. In this context, projects related to the scientific guidance and coordination of regional universities and the promotion of cultural intangible heritage with the encouragement of relevant public institutions should be carried out.

Under the indicator of the state of the modern, traditional, monumental heritage, 278 restoration projects were prepared between 2008-2012, and according to the number of projects prepared for the restoration, preservation and maintenance of cultural 
values several funds were allocated to these projects. A total of TL 15.203.082, 91 of funding was granted to these projects. Moreover, it was emphasized by the regional stakeholders that the projects were prepared for the restoration, maintenance and protection of many historical buildings in the region by Eastern Black Sea Development Agency, Ministry of Culture and Tourism, General Directorate of Foundations and Special Provincial Administrations. On the other hand, there are a few issues to be put forward in this regard such as the failure to preserve the historic fabric and structures so that allowing them to destroy, and restorations in some tourist areas led the original structures to lose their originality.

According to the results of the indicator of seasonal and full-time employment in accommodation businesses under the tourism social impact indicator on employment, the study result shows that full-time employment in the businesses has a ratio of $75 \%$ or more. Moreover, it can be uttered that the rates of seasonally employed personnel in Trabzon, Rize and Artvin are higher than the other three provinces, where the tourism arrivals tend to be higher than the others. Some other points that were revealed by the regional stakeholders are the reduced service quality in seasonal employment, increased turnover rate, and lack of customer satisfaction, and so on.

Among the sustainable tourism social indicators come the accommodation arrangements for disabled guests. Disabled room services provided by the accommodation businesses located in the Eastern Black Sea Region has been evaluated under this indicator title. According to the results of the research, it was recognized that approximately $65 \%$ of the accommodation businesses do not possess any rooms for the disabled. In line with the sustainable tourism approach, more accommodation businesses should take action to enable the access of the disabled to tourism services so that a contribution to sustainable tourism development in the region may be achieved.

According to the indicator of the number of personnel at hospitals and the bed capacity at hospitals in the region under the heading of the general state of health indicator, it can be said that general increases in nominal values were achieved in 20082012. There are qualified universities, public and private hospitals in the region where the health needs of tourists can be met. However, it is harshly criticized by locals that the shortages of health centers, hospitals and health personnel in the tourism areas such as Uzungöl and Ayder Plateau, where tourism arrivals are concentrated in the region, are on the rise.

Solid wastes collected by municipalities within the context of the collection, reuse and conversion systems of solid wastes, one of the environmental indicators of sustainable tourism, and solid wastes collected in 2008-2012, except 2 provinces, increased according to the results of the ratio of the population compared to the total population of waste service. On the other hand, solid waste services, in general, are provided by the municipalities in more than $60 \%$ of the provincial population in the districts. Sewerage infrastructure is an obstacle that needs to be emphasized concerning solid wastes in the region, especially in festivals, during which the use of solid wastes, conversion, and reuse systems is low.

The average sulfur dioxide (SO2) and particulate matter (PM10) results for the winter period on the emission level indicator in the districts are evaluated in the category of environmental indicators. According to this data, the first level warning threshold (> $260 \mu \mathrm{g} / \mathrm{m}^{3}$ ) in sulfur dioxide average has been exceeded twice in the winter season of $2012 / 2013$ in Trabzon. In relation to the average of particulate matter, the warning 
threshold was not exceeded between 2008-2012 in the provinces of region. On the other hand, Giresun attained the lowest value of $14 \mu \mathrm{g} / \mathrm{m}^{3}$ in the average of the winter season of particulate matter in the $2011 / 2012$ winter season. Despite the results obtained from the secondary data, the environmental pollution caused by the coal fuel used for heating in Trabzon, Giresun and Ordu provinces has been brought up during the interviews with stakeholders.

Sustainably managed afforested areas and erosion control work are other environmental indicators used to determine the extent of environmental damage in tourism areas. In the given years, there is no sustainable rise in afforestation areas and erosion control work in the region. When planning the sustainable tourism development strategy in the region, it may be helpful to take tourism investment decisions by looking at protection/usage balance in sensitive areas and to take sustainable measures in areas where erosion is intense.

The Eastern Black Sea Region is one of the regions where the number of vulnerable and protected areas is higher than the country average. There are 37 protected areas in the region, including national parks, nature parks, nature protection areas and natural monuments. There are many tourist facilities in these areas where the needs of tourists are satisfied. Investments without considering the protection/use balance in protected areas will undoubtedly damage environmental sustainability in the long-term. Illegal construction, facility investments made without taking environmental carrying capacity into account may damage the sustainability of protected areas.

When the gross production quantities and the changes in installed capacity of the hydroelectric power plants where the study and project works were carried out are checked out in the scope of the capacity and usability of the renewable energy reserves and the network, it may be commented that there is a remarkable and gradual increase in both the capacity of the hydroelectric power plants and in the gross production amounts. Additionally, there are many hydroelectric power plant investments in the investment plans of the region in the coming years. These plants, which were opened and planned to be opened to operate on streams, rivers and rivers with sustainable tourism potential will undoubtedly damage the environmental sustainability of the region. It was alleged by tourism stakeholders that one of the most important hurdles hampering the sustainable tourism development of the region is the investment in hydroelectric power plants.

Considering the number of tourism projects and the amount of funds provided within the scope of the indicator subject, the effectiveness of planning, control and management systems in the planning and control indicators category, it was obtained that 260 tourism projects were supported by the Eastern Development Agency. Project support for these projects totaled TL 21,088,121.99. The number of tourism projects and support amounts for 2010 is the highest year. It was emphasized by the tourism stakeholders during interviews that the Eastern Black Sea Development Agency makes affirmative contributions to sustainable tourism development in the region. In this scope, it may be claimed that the number of meetings, trainings and seminars organized by the Eastern Black Sea Development Agency for the tourism sector stakeholders is another firm indicator.

\section{Conclusion and Discussion}

Sustainable tourism is an approach that focuses on the preliminaries of the sources of destructive elements in tourism, in which medium and long-term planning processes are 
identified in line with stakeholder management principles, along with reconsidering the regions in terms of their strengths and weaknesses. Particularly by employing the sustainable tourism indicators, the harmonization of the tourism development strategies of the regions through their economic, socio-cultural and environmental conditions is evaluated. Just as in many other areas, there are significant barriers to obtaining indicator data sets periodically or in a way that enables the researchers to make comparisons between certain years. The most leading constraint in this study is that public institutions, tourism operators and other stakeholders were insufficient in recording their data and archiving them and were also reluctant to analyze or share the indicator data with researchers.

Eastern Black Sea Region takes its place among the newly discovered tourism areas of our country with its nature, protected areas and tablelands. Tourists, particularly the ones coming from the Middle East countries, visit tourist attractions in Trabzon, Giresun, Ordu, Rize, Artvin and Gumushane in the Eastern Black Sea Region. The main emphasis here is whether tourism activities in the region have sustainable qualities. It is essential to take the extent of the destruction and the limits of the carrying capacity in the region into account as the destruction by tourism is not irreversible. Thus, the planning and implementation processes should be utilized under the guidance of sustainable tourism indicators.

It seems that tourism in the Eastern Black Sea Region is an inevitable industry in terms of changing the region's traditional rural function and diversification of tourism (Bakırcı, 2012). Tourism constitutes an important potential for the traditional livelihoods of local people. For example, Bakirci (2012) stated that in a study conducted in Yaylalar Village in the Yusufeli district of Artvin province, tourism has a $20 \%$ share of economic activities. Although tourism is regarded as an economic necessity among regional stakeholders in this research as well, it is emphasized that the decisions to be taken considering the short-term economic benefit will be unsustainable for the region in the medium and long term.

In the region, with the support of Eastern Black Sea Development Agency, restoration, roads, etc. infrastructure and superstructure capacity-building projects were actualized in tourism regions. Apart from the Development Agency, Small and MediumSized Enterprises Development and Support Administration (KOSGEB), Municipalities, Special Provincial Administrations and some other public institutions provide support to investors in the region. According to the findings of this research, it was made clear that the Eastern Black Sea Development Agency (DOKA) has made remarkable contributions to the tourism of the region through financing the investments in the region, bringing stakeholders together and training them. It is recommended by this study that the bureaucratic formalities be minimized in the process of project application, evaluation and control and the projects that will not prevent environmental destruction be supported.

Investments in hydroelectric power plants are a source of pressure on tourism areas in the region. Therefore, it is asked by the locals that the authority not grant any permission for the construction of the power plants in regions such as İkizdere Valley, Fırtına Valley, Artabel Valley, etc. where tourism arrivals centered and the environmental impact assessment criteria be followed when hydroelectric power plant investments are planned in the region. On the other hand, a study by Ürker and Çobanoğlu (2012) emphasized the necessity of carrying out integrated basin planning in the regions where HEPP projects are planned and determining different values and usage elements in the basins. In addition, in the same research it was stated that the HEPPs operating without 
integrated basin planning will create landslide risk in the Eastern Black Sea and lead to irreversible environmental damages.

The tablelands are areas of tourist attraction in the Eastern Black Sea Region. Noncertified accommodation investments in the tablelands, which do not use natural materials, do not comply with the principles of sustainable tourism. Demirel and Ejder (1995) point out that the use of local architecture examples of home-boarding should be encouraged instead of hotels and motels facilities in the tablelands and the density of the visitors at the tableland festivals should be included in the planning. Another issue is that the chalet construction, which is in harmony with nature, is replaced by unplanned, makeshift, two- or three-story reinforced concrete buildings that are no longer in harmony with the local architecture. (Bekdemir and Özdemir, 2002: 30). This state lead to architectural pollution in the tablelands and damages the sustainability of tourism activities in the region. Similarly, it was suggested in a research by Doğanay (2009) that tableland tourism should not adversely affect the traditional plateauing activities, the local elements should be considered as a part of sector and the traditional lifestyle and architecture of tablelands should be preserved. The local stakeholders have emphasized the fact that architectural pollution in the valleys is still going on. In order to overcome this situation, problems arising from the legislation in the construction of tourism facilities or houses should be solved, and illegal construction should not be allowed.

The education levels of employed in the tourism sector in the region are not at the desired level. In addition, there are problem areas such as the insufficient level of foreign language among the employees, the fact that the tourism professions are not evaluated within the scope of dependent work, seasonality, low wages, excessive working hours, and educated employees prefer advanced tourism areas such as Antalya and Muğla. For the solution of these problems, it is recommended to raise the awareness of local people and tourism enterprises on tourism education, to increase the quality of foreign language and professional practice education in universities, and to take legal measures to improve the personal rights and working conditions of the employees.

Finally, it can be said that creating a structure that will contribute to the sustainable development of the Eastern Black Sea Region and including all stakeholders in the planning processes under the guidance of sustainable tourism indicators can be a key element of tourism development in the region. On the other hand, a system of economic, socio-cultural and environmental standards with the support of the people of the region should include the sustainable elements of tourism development in the region rather than the elements that will limit and destroy the values and belief system of the people, which are incompatible with the traditions of the local people and therefore will not be adopted by the people of the region. Otherwise, the effect of destruction arising from mass tourism on issues such as family and cultural relations, environmental processes and economic gains of local people will not have positive consequences for the region in the long term.

\section{References}

Aspinall, A. J. (2006). Communities in change: social sustainability and tourism development. Unpublished Master Thesis. University of Waterloo Applied Environmental Studies: Ontario.

Bahar, O. and Kozak, M. (2010). Tourism economics. Ankara: Detay Publishing.

Bakırcı, M. (2012). Impact of tourism on diversifying economical activities in rural settlements: Case of Yaylalar Village (Yusufeli / Artvin). East Geography Journal, 57, p: 71-85. 
Bal, H. (1995). Tourism impact on family relationships in rural society. İstanbul: Doğaİnsan Publishing.

Bekdemir, Ü. and Özdemir, Ü. (2002). An Example to Developing Centers of Plateau Tourism in Black Sea Region: Bektas Plateau. East Geography Journal, (7) (30), p: 9-35.

Castellani, V. (2009). Development of methodologies and indicators to assess sustainability in tourism and agriculture, Unpublished Doctorate Thesis, University of Milano, Department of Environmental Science and Technology: Milano.

Ceron, J.P. and Dubois, G. (2003). Tourism and sustainable development indicators: The gap between theoretical demands and practical achievements. Current Issues in Tourism, 6(1), p: 54-75.

Choi, C. H. and Sirakaya, E. (2006). Sustainability indicators for managing community tourism. Tourism Managament, 2, p: 1274-1289.

Demirel, Ö. and Ejder, N. (1995). Çamlıhemşin tablelands and nature tourism activities. Ekoloji Journal. 17, p: 4-8.

Doğanay, S. (2009). A geographıcal approach to the tourısm potentıal of Cami Boğazı High Plateau and Çakırgöl in view of protection-usage balance. East Geography Journal, 14 (22), p: 165-186.

Farsari, Y. and Prastacos, P. (2001). Sustainable tourism indicators: Pilot estimation for the municipality of Hersonissos, Crete. Athens: Regional Analysis Division, Institute of Applied and Computational Mathematics, Foundation for the Research and the Technology Hellas.

Goodwin, H. (1998). Sustainable tourism and poverty elimination, DFID/DETR Workshop on Sustainable Tourism and Poverty. 13 October 1998. Faversham.

Hunter, C. and Shaw, J. (2007). The ecological footprint as a key indicator of sustainable tourism. Tourism Managament, 28, p: 46-57.

Kahraman, N. ve Türkay, O. (2014). Turizm ve çevre. Ankara: Detay Publishing.

Liu, Z. (2003). Sustainable tourism development: A critique. Journal of Sustainable Tourism, 11(6), p: 459-475.

Miller, G. (2001). The development of indicators for sustainable tourism: results of a delphi survey of tourism researchers. Tourism Management, 22, p: 351-362.

Murphy, P.E. and Price, G.G. (2005). Tourism and Sustainable Development. W. F. Theobald (Ed) Global Tourism, Burlington: Elsevies-Heinemann Publishing.

Reilly, J. M. (2008). Building future tourism environments: Towards more eco-efficient destination transportation systems. Unpublished Master Thesis. Thompson Rivers University, School of Resource and Environmental Management of Resource Management: Wellington.

Schianetz, K. and Kavanagh, L. (2008). Sustainability indicators for tourism destinations: A complex adaptive systems approach using systemic indicator systems. Journal of Sustainable Tourism, 16(6), p: 601-628.

Sharpley, R. (2006), Travel and tourism, California: Sage Publications.

Somuncu, M., Kaya, N.Ç., Kurum, E., Akpınar, N. ve Eceral, Ö.T. (2012). Doğu Karadeniz yaylalarında çevresel değişim, Ankara: Ankara University Publishing.

Speier, J. V. (2005). Sustainable development and tourism, Unpublished Doctorate Thesis. University of Southern California, Faculty of the School of Policy, Planning and Development: California.

Tanquay, G., Therrien, M. C. and Rajaonson, J. (2011). Sustainable tourism indicators: Selection criteria for policy implementation and scientific recognition. Montreal: CIRANO Scientific Series, p.60.

Tokmak, C. (2008). Carrying capacity for sustainable tourism: Topkapı Palace example, Unpublished Doctorate Thesis, Gazi University, Institute of Educational Sciences: Ankara. 
Tosun, C. (2002). Host perceptions of impacts a comparative tourism study. Annals of Tourism Research, 29(1), p: 231-253.

United Nations World Tourism Organisation (UNWTO) (2004). Indicators of sustainable development for tourism destinations: A guide book. Madrid: UNWTO Publishing.

United States World Tourism Organizations (2015). UNWTO tourism highlights 2015 edition, http://www.e-unwto.org/doi/pdf/10.18111/9789284416899 (12.10.2018).

United States World Tourism Organizations (UNWTO) (2020). International tourism growth continues to outpace the global economy. https://unwto.org/internationaltourism-growth-continues-to-outpace-the-economy (01.03.2020).

Ürker, O. and Çobanoğlu, N. (2012). Evaluation of hydroelectric power plants in Turkey in the context of environmental policies, Journal of Ankara University Social Sciences Institute, 3(2), p: 66-88. 